В. П. Бибель, В. С. Глухов, О. В. Пристопюк* Національний університет “Львівська політехніка", кафедра електронних обчислювальних машин, *кафедра теоретичної радіотехніки та радіовимірювань

\title{
ВИБІР БЕЗДРОТОВОЇ ТЕХНОЛОГІЇ ПЕРЕДАВАННЯ ДАНИХ ДЛЯ ОБЛАДНАННЯ НАВЧАЛЬНИХ ЛАБОРАТОРІЙ
}

\author{
() Бибель В. П., Глухов В. С., Пристопюк О. В., 2016
}

Наведено результати дослідження, оцінювання та порівняння бездротових технологій передавання даних, які можна використати для побудови систем збирання та керування даними у лабораторіях навчальних закладів. Обгрунтовано доцільність роботи у цьому напрямі на основі аналізу сучасних тенденцій розвитку комп'ютерних мереж та систем. Пропонується використання протоколу Bluetooth Low Energy як одного із способів модернізації процесів постановки наукових дослідів та адаптації навчального процесу вищої освіти в Україні до вимог суспільства та ринку праці.

Ключові слова: бездротові технології, передавання даних, Bluetooth Low Energy, ZigBee, Z-Wave, Wireless USB, ANT.

\section{ANALYSIS OF DATA WIRELESS TECHNOLOGIES FOR EDUCATIONAL PROCESS MODERNIZATION}

(C) Hlukhov V., Bybel V., Pristopiuk O.

The article presents the results of research, evaluation and comparison of wireless data transmission technologies that can be used in the construction of the collection and management of data system for the scientific and educational institutions. An expediency of the study in this direction made by analyzing the current trends of computer networks and systems. It is proposed to use Bluetooth Low Energy Protocol as a way of modernizing the processes of setting scientific research and adaptation of the educational process of higher education in Ukraine with the requirements of society and the labor market.

Key words: wireless technology, data transmission, Bluetooth Low Energy, ZigBee, ZWave, Wireless USB, ANT.

\section{Ветуп}

Побудова гнучких мереж збирання та керування даними є завданням, яке постійно актуальне в різних галузях науки та промисловості. Для прикладу варто перерахувати лише деякі 3 таких сфер застосування: 1) керування технологічними процесами на виробництві управління роботою промислових об`єктів; 2) автоматизація досліджень у різних галузях науки - системи реєстрації результатів експерименту, контролю обладнання та вимірювальних приладів; 3) моніторинг, диспетчеризація та керування станом “чистих" кімнат у медицині; 4) застосування в побуті системи "розумного будинку" та пультової сигналізації, автоматичного збирання показників приладів обліку енергоносіїв; 5) автоматизація індивідуального обладнання - системи моніторингу стану здоров`я людини; 6) системи автоматизації навчальних стендів та обладнання.

Розвиток телекомунікаційних технологій відбувається за двома основними напрямами: збільшенням пропускної здатності каналів зв'язку та переходом до використання мобільних 
технологій. Ця тенденція спостерігається і в системах збирання та керування даними, переважно через численні вигоди, які отримують системні інтегратори та користувачі від застосування бездротових рішень.

Великої популярності набули модулі на основі систем на кристалі - інтегральних схем, в яких об'єднано в одному корпусі радіотракт однієї чи декількох технологій бездротового передавання інформації, мікроконтролер та периферійні модулі: інтерфейси, ЦАП/АЦП, програмовану логіку та ін. Все це разом 3 помірною ціною дає можливість створити гнучку систему збирання та керування даними для різноманітних сфер застосування.

Під час наукової та навчальної роботи виникає необхідність проведення вимірювань, тестів, дослідів, що вимагають використання давачів для моніторингу і контролю перебігу процесів.

У статті результати останніх досліджень у цій сфері розглянуто з погляду практичного застосування існуючих технологій для модернізації навчального та наукового процесу.

\section{1. Аналіз останніх досліджень та публікацій}

У [1] проаналізовано моделі збирання інформації та їх оптимізації в бездротових сенсорних мережах. Автори [2] запропонували втрішення проблеми моніторингу стану висотних будівель, а в [3] наведено особливості реалізації бездротових сенсорних мереж. У [4] подано огляд Bluetooth Low Energy протоколу, а в [13] досліджено функціонування та формування мереж Scatternet та Piconet, побудованих 3 використанням бездротових технологій. Інформацію про бездротові технології Z-Wave [5], ZigBee [6], ANT [7], Wi-Fi [8] та Wireless USB [9] наведено на офіційних сайтах організацій, що займаються розвитком цих технологій. У [10] досліджено використання специфікації мережевих протоколів верхнього рівня ZigBee для організації роботи готелю Aria (Лас-Вегас). У статті [11] описано проектування та функціонування мережі 3 mesh-топологією. GFSK-модуляцію розглянуто в [12].

\section{2. Окреслення проблеми}

Використання сучасних протоколів та рішень для розв'язання задач модернізації процесів науково-дослідної і навчальної діяльності, а також організації лабораторного обладнання детально в згаданих роботах не розглядалося.

Ефективне використання лабораторного обладнання передбачає виконання таких вимог:

- апаратна частина повинна бути доступною (COTS);

- забезпечення певного рівня універсальності - передбачено, що система зможе працювати з давачами різних виробників;

- кількість вузлів - 2..10;

- доступність програмного забезпечення (ПЗ);

- низьке енергоспоживання - .розроблювана система в окремих випадках матиме безперебійне джерело живлення, але частіше іï вузли будуть розташовані в місцях, важко доступних для людини, або місцях, що вимагають стерильності, наприклад, у “чистих кімнатах". Саме тому забезпечити можливість незалежного живлення від батареї є важливою вимогою. Але способи виконання цих вимог та проектування такої системи у літературі не висвітлено.

\section{3. Мета публікації}

Метою роботи $є$ аналіз сучасних технологій бездротового передавання даних для вибору типу мережі при створенні системи збирання та керування даними учбових лабораторій у навчальних закладах. 


\section{4. Огляд сучасних бездротових технологій передавання даних}

Для передавання даних зараз активно використовуються такі протоколи: Z-Wave/ZWave Plus, ZigBee, Bluetooth Low Energy, ANT/ANT+, Wireless USB, Wi-Fi. У табл. 1 наведено основні їх характеристики, що впливають на вибір одного 3 них в межах розв'язання поставленого завдання.

Протоколи Z-Wave Plus/Z-Wave

Z-Wave Plus - це протокол бездротового зв'язку, розроблений для побутової автоматизації, зокрема, керування обладнанням в офісах і приватних оселях (технологія “Розумний будинок”).

Протокол забезпечує сумісність пристроїв різноманітних виробників і працює на частотах до 1ГГц. Це дозволяє не використовувати додаткових заходів для зменшення впливу завад, які існують при роботі на частоті 2,4 Гц. В умовах прямої видимості досягається швидкість передавання даних на відстань до 30 м.

В основу Z-Wave покладено mesh-топологію, в якій кожен вузол або пристрій може приймати і передавати керуючі сигнали іншим пристроям мережі, використовуючи проміжні сусідні вузли.

Переваги протоколу:

- віддалений моніторинг мережі через Інтернет чи мобільний телефон;

- зручність масштабування;

- мережа може бути побудована з допомогою ПЗ з відкритим кодом.

Недоліки протоколу:

- початковий запуск мережі вимагає роботи групи висококваліфікованих спеціалістів;

- для мереж 3 кількістю вузлів понад 30 ціна реалізації мережі стає вищою, ніж ціна відповідних кабельних мереж;

- у зв'язку з конструктивними особливостями мережі мають обмежений радіус дії і масштаби.

Отже, можна зробити висновок про можливість використання цієї технології для комерційних застосувань за необхідності створення мережі з обмеженою кількістю вузлів.

Порівняння мереж бездротового зв'язку

\begin{tabular}{|c|c|c|c|c|c|c|}
\hline & ZigBee & Z-Wave & BLE & ANT & Wi-Fi & W-USB \\
\hline $\begin{array}{l}\text { Частотний } \\
\text { діапазон, } \\
\text { МГц }\end{array}$ & $868 / 915 / 2400$ & $\begin{array}{c}\text { 8968/908(всі) } \\
2400(\text { с.400) }\end{array}$ & $2400-2483$ & $2400-2483$ & $\begin{array}{l}2483- \\
5500\end{array}$ & $3100-10600$ \\
\hline $\begin{array}{c}\text { Швидкість } \\
\text { передавання, } \\
\text { Кбіт/с }\end{array}$ & $20 / 40 / 250$ & $\begin{array}{c}9.6 / 40 \\
(3200 \text { c.) } \\
200(\mathrm{c} .400)\end{array}$ & 1000 & 1000 & $\begin{array}{c}100- \\
>54000\end{array}$ & $\begin{array}{l}110000- \\
480000\end{array}$ \\
\hline $\begin{array}{c}\text { Кількість } \\
\text { вузлів }\end{array}$ & $\begin{array}{c}1 \text { маршругизатор } \\
\text { обслуговує до } \\
32 \text { вузлів }\end{array}$ & $\begin{array}{c}1 \text { маршрутизатор } \\
\text { обслуговує до } 32 \\
\text { вузлів }\end{array}$ & $\begin{array}{c}1 \text { ведучий } \\
\text { обслуговує } \\
7 \text { ведених }\end{array}$ & $\begin{array}{c}1 \text { ведучий } \\
\text { обслуговус } \\
7 \text { ведених }\end{array}$ & $\begin{array}{c}\text { Мін. } 2 \\
\text { вузла }\end{array}$ & $\begin{array}{c}1 \text { хост } \\
\text { обслуговує } \\
\text { до } 127 \\
\text { вузлів }\end{array}$ \\
\hline Радіус дії, м & $10-100$ & $30-100$ & 50 & 30 & 150 & 3-100 \\
\hline $\begin{array}{c}\text { Типи } \\
\text { пристроїв чи } \\
\text { ролі вузлів }\end{array}$ & $\begin{array}{l}\text { Координатор, } \\
\text { маршрутизатор, } \\
\text { кінцевий } \\
\text { пристрій }\end{array}$ & $\begin{array}{c}\text { Координатор, } \\
\text { маршрутизатор, } \\
\text { ведений }\end{array}$ & $\begin{array}{l}\text { Ведучий і } \\
\text { ведений }\end{array}$ & $\begin{array}{c}\text { Ведучий і } \\
\text { ведений }\end{array}$ & $\begin{array}{c}\text { Точка } \\
\text { доступу, } \\
\text { клієнт }\end{array}$ & $\begin{array}{c}\text { Хост, } \\
\text { перифе- } \\
\text { рійний } \\
\text { пристрій }\end{array}$ \\
\hline $\begin{array}{c}\text { Піковий } \\
\text { струм } \\
\text { спожи-вання } \\
\text { вузла, мА }\end{array}$ & $<150$ & $\begin{array}{c}21 \text { (режим } \\
\text { пробудження) } \\
36 \text { (режим } \\
\text { передачі) }\end{array}$ & 12,5 & 17 & $\begin{array}{l}116 \\
\text { (при } \\
1,8 \mathrm{~B})\end{array}$ & $<<500$ \\
\hline
\end{tabular}




\section{Протокол ZigBee}

ZigBeе - специфікація мережних протоколів верхнього рівня, які використовують сервіси нижніх рівнів - рівня МАC і фізичного рівня РНY. Протокол ZigBee гарантує безпечне передавання даних при відносно невисоких швидкостях (20-40 Кбіт/с) і можливість роботи мережних пристроїв від автономних джерел живлення (батареї типу ААА). Технологія ZigBee реалізує mesh-топологію мережі та забезпечує автоматичну ретрансляцію повідомлень з підтримкою мобільних вузлів.

Сьогодні ZigBee застосовують для створення сенсорних мереж, реалізації технології “Розумний будинок”, систем комунального призначення, охоронних систем, систем керування в промисловості.

Стандарт ZigBee забезпечує найвищі швидкості передавання даних та найвищу завадостійкість у діапазоні 2,4 ГГц. Швидкість передавання даних разом зі службовою інформацією становить 250 Кбіт/с. При цьому середня пропускна здатність вузла для корисних даних залежно від завантаженості мережі і кількості ретрансляцій у межах 5-40 Кбіт/с.

Відстань між вузлами мережі 10-20 метрів під час роботи в приміщенні і сотні метрів при відкритому просторі, завдяки ретрансляції зона покриття мережі може бути збільшена.

Однією $з$ переваг і водночас недоліком технології $є$ iї складність. Перевага полягає у тому, що така архітектура забезпечує високу надійність і живучість мережі, а недоліком є значна ціна побудови.

Мережу будують з використанням:

- координатора, що запускає мережу, виконує функції центру керування мережею і центру довіри - встановлює політику безпеки, задає налаштування в процесі приєднання пристроїв в мережу, завідує ключами безпеки. Очевидно, що вихід 3 ладу координатора спричиняє непрацездатність всієї мережі;

- маршрутизатора, який транслює пакети, виконує динамічну маршрутизацію, тому прямий зв'язок між двома кінцевими пристроями ZigBee неможливий. Розробнику необхідний і координатор, і маршрутизатор для встановлення зв'язку лише двох пристроїв.;

- кінцевого пристрою, що може приймати і передавати пакети, але не може займатися їх трансляцією і маршрутизацією. Кінцеві пристрої не можуть мати дочірніх пристроїв, а мають бути підключеними до координатора чи маршрутизатора. Саме кінцеві пристрої працюють 3 давачами.

Технологія ZigBee використовує 16-бітну адресацію, тобто теоретично один координатор може взаємодіяти 3 понад 65000 пристроями. Разом 3 тим можлива робота одночасно декількох мереж. Наприклад, в готелі Aria (Лас-Вегас) [10] розміщено близько 75000 пристроїв з підтримкою ZigBee. Мережа такої складності вимагає знань і компетенції для налаштування та обслуговування.

У зв'язку з описаними вище характеристиками цей протокол підходить для реалізації мереж зі значною кількістю вузлів корпоративного, промислового та військового напрямку, забезпечить високий рівень надійності і працездатності навіть при пошкодженні мережі.

\section{Протоколи Bluetooth Low Energy}

Bluetooth Low Energy (BLE) - протокол для створення персональних мереж, основними сферами застосування є охорона здоров'я, спорт, охоронні системи, індустрія розваг, побутові застосування, інтернет-речей (IoT).

Істотною перевагою специфікації $\epsilon$ наднизьке пікове енергоспоживання, середнє енергоспоживання і енергоспоживання в режимі простою, що дасть змогу створити систему, яка працює з давачами безперервно та не вимагає постійного джерела живлення. 
Мобільні операційні системи, зокрема IOS, Android, Windows Phone i BlackBerry, а також OS X, Linux i Windows 8 мають вбудовану підтримку Bluetooth Low Energy (інша назва - Bluetooth Smart). 3 вищеозначеного випливає поширеність цієї технології, що $\epsilon$ значною перевагою. BLE, на жаль, не має зворотної сумісності з попереднім (так званим “класичним”) протоколом Bluetooth.

Специфікація Bluetooth 4.0 (i пізнші) фактично визначає дві бездротові технологіï: BR / EDR i стандарт BLE. Пристрої, в яких застосовано BLE, можуть бути як дворежимні BR / EDR / BLE (Bluetooth Smart - Ready), сумісні з класичними Bluetooth-пристроями, так i однорежимні BLE (Bluetooth Smart).

Основними блоками Bluetooth-пристроїв є:

- програма - реалізує логіку роботи;

- ведучий пристрій, хост - реалізує верхні рівні стека протоколів Bluetooth;

- контролер - реалізує нижні рівні стека протоколів Bluetooth.

Комерційні продукти зазвичай виконано в одному з таких апаратних рішень:

- система на кристалі - однокристальна система, що об'єднує програму, хост i контролер, застосовується в компактних пристроях, наприклад, в давачах;

- рішення на двох мікросхемах, при якому додаток і хост з'єднано з контролером за допомогою UART, USB, SDIO i т. п. за протоколом HCI. Така конфігурація може використовуватися, наприклад, в мобільних пристроях;

- рішення на двох мікросхемах, при якому хост і контролер з'єднано за пропрієтарним протоколом;

- програмоване радіо на кристалі - однокристальна система, яка об’єднує мікроконтролер, апаратно реалізований модуль Bluetooth та програмовану логіку.

BLE визначає 40 радіочастотних каналів 3 кроком 2 МГц. Адаптивний механізм стрибкоподібної перебудови частоти використано для протидії перешкодам, загасанню сигналу та інтерференції. Цей механізм вибирає один 337 доступних каналів передавання даних для зв'язку протягом заданого часового інтервалу.

Усі фізичні канали використовують GFSK-модуляцію [12]. Коефіцієнт модуляції знаходиться в діапазоні від 0,45 до 0,55 , що забезпечує знижену пікову споживану потужність.

Протокол ANT/ANT+

$\mathrm{ANT} / \mathrm{ANT}+$ - це пропрієтарний протокол, розроблений для обміну даними 3 сенсорами, що знаходяться на відстані 1 - 5 м. Переважно це: давачі серцевого ритму, давачі швидкості, давачі тиску тощо. Цей протокол має певні переваги над BLE в сфері енергоспоживання, а caмe:

- менше споживає електроенергії при оголошенні сервісу;

- менше споживає електроенергії при скануванні та ініціюванні сеансу зв`язку;

- потребує менше трансакцій для кожного етапу сеансу зв'язку;

- при відправці однакового об'єму даних пересилає менше службової інформації.

Протокол реалізує топології: точка-точка, “зірка”, “дерево”. Згідно з специфікацією дозволяє мережі розміром до 65533 вузлів.

$\mathrm{ANT}+\epsilon$ адаптивним синхронним протоколом. Мережа утворюється логічними з'єднаннями пар вузлів. При цьому один вузол грає роль ведучого, а другий - веденого. Але тому ж веденому дозволено бути ведучим відносно іншого вузла, з яким у нього інше логічне з'єднання.

Протокол ANT $+\epsilon$ протоколом з відкритим кодом, та основним недоліком його $є$ менша поширеність порівнянно з BLE чи ZigBee. 


\section{Протокол Wireless USB (W-USB)}

Wireless USB (W-USB) - технологія, створена у зв'язку з популярністю USB інтерфейсу і покликана забезпечити переваги USB у сфері бездротового зв`язку. Ця технологія забезпечує швидкість 480 Мбіт/с на відстані до 3 метрів і 110 Мбіт/с на відстані до 10 метрів, що

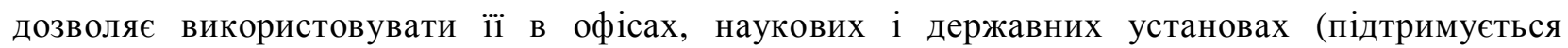
багатьма принтерами, сканерами, цифровими камерами, жорсткими дисками тощо) та в побуті (гейм-плеї, домашні кінотеатри, побутова техніка).

Wireless USB архітектура дозволяє підключення до 127 пристроїв безпосередньо до хоста, який $є$ унікальним для системи і переважно інтегрований у комп'ютер. Для безпечного 3'єднання використовуються механізми авторизації і шифрування з'єднання.

Та, незважаючи на високу швидкість передавання W-USB на частоті 3.1-10.6 ГГц, модулі цієї технології є дорогими та важкодоступними в непромислових кількостях.

Протокол Wi-Fi

$\mathrm{Wi}-\mathrm{Fi} \epsilon$ протоколом, що дозволяє електронним пристроям підключатися до бездротової мережі LAN, переважно з використанням 2,4 ГГц і 5 ГГц радіодіапазонів. Протокол є одним 3 найпоширеніших, існує значний об'єм літератури, де його описано.

Цей протокол не підходить для вирішення поставленого завдання у зв'язку з такими особливостями: високе енергоспоживання, надлишковість трафіка, ненадійність з'єднання, вразливість до атак тощо.

\section{5. Аналіз і вибір рішення}

Протокол ANT/ANT+, незважаючи на те, що забезпечує найнижче в середньому енергоспоживання, не підходить, оскільки не є достатньо поширеним. При використанні ANT/ANT+ система не відповідатиме пред`явленим вимогам.

Протокол W-USB є надлишковим, оскільки немає необхідності забезпечення значних швидкостей, до того ж висока ціна модулів у непромислових кількостях також стає на заваді. Протокол вимагає значних (таблиця) енерговитрат, що є неприйнятним.

Протоколи Z-Wave Plus/Z-Wave у зв'язку з складністю початкового налаштування, але більше через низьку ефективність при невеликій кількості вузлів будуть не найоптимальнішим рішенням поставленого завдання.

Протокол ZigBee - рішення для територіально розкиданих складних мереж, яким насаперед потрібно забезпечити стабільний зв`язок при надзвичайних ситуаціях. Але саме

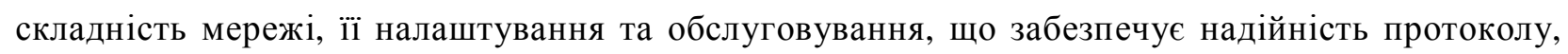
стає перешкодою при реалізації завдання. Адже необхідно, щоб розгортання системи займало як найкоротший часовий проміжок, і щоб систему було легко налаштувати. У зв`язку з цим цей протокол стає непридатним для реалізації поставленого завдання.

Протокол $\mathrm{Wi}-\mathrm{Fi}$, що показав себе в ролі провідного бездротового протоколу передавання даних для пристроїв з високим запасом електроенергії, для поставлених цілей не підходить.

Протокол Bluetooth Low Energy, на основі проведеного аналізу, є найприйнятнішим для реалізації поставленого завдання сьогодні. Звичайно, протокол має суттєві недоліки з огляду на поставлене завдання, а саме, не має стандартизованої процедури обміну між двома і більше мережами Piconet, що ускладнює об`єднання декількох мереж Piconet для проведення складніших вимірювань і аналізу більшого об`єму даних, для подальшого вдосконалення i розширення мережі.

3 іншого боку, цей протокол відповідає всім висунутим вимогам, що дає можливість застосувати його для реалізації системи керування i збирання даних при наукових експериментів, тестувань, розгортання систем вимірювання і моніторингу на короткий проміжок часу (тижні). 
У зв'язку з представленими вимогами до системи раціональним рішенням буде використання протоколу Bluetooth Low Energy.

\section{6. Подальший напрямок роботи}

Результати аналізу дають основу для проектування бездротового модуля введеннявиведення системи збирання та керування даними для проведення навчальних та наукових експериментів. Цей модуль може бути в подальшому використаний для створення мережі, що охопить лабораторне приміщення, а в перспективі і будівлю наукової установи.

Подальший напрямок роботи полягає у дослідженні основних закономірностей роботи мережі таких бездротових модулів у межах мережі Piconet, а надалі і в межах мережі Scatternet.

\section{Висновки}

Проведений аналіз сучасних технологій бездротового передавання даних показав, що сьогодні протокол передавання даних Bluetooth Low Energy як найповніше відповідає меті модернізації навчальних лабораторій. Пропонується використання цієї технології для проектування системи збирання та керування даними лабораторного обладнання навчальних закладів.

1. Галкін П. В. Аналіз моделей та оптимізащії збору інформащії в бездротових сенсорних мережах // Східно - Європейський журнал передових технологій. - Харків, 2014. - Вип. 71. C. 24-30 2. Feng Wang, Dan Wang, Jiangchuan Liu Elesense: elevator-assisted wireless sensor data collection for high-rise structure monitoring. Proceedings - IEEE INFOCOM. March, 2012 3. O. В. Тимченко, М. Ю. Зеляновський. Особливості реалізації сенсорних мереж бездротового доступу. Збірник наукових праць Інституту проблем моделювання в енергетииі ім. Г.С.Пухова НАН України. - К.: IПМЕ ім. Г.С.Пухова НАН України, 2010. - Bun. 54. - C. 137-144. 4. Carles Gomez, Joaquim Oller, Josep Paradells. Overview and Evaluation of Bluetooth Low Energy: An Emerging Low-Power Wireless Technology. Sensors (Basel). 2012; PP. 11734-11753. 5. Z-Wave Alliance, http://z-wavealliance.org/ 6. ZigBee Alliance, http://www.zigbee.org 7. ANT Alliance, https://www.thisisant.com/ 8. Wi-Fi Alliance, http://www.wi-fi.org/ 9. "Wireless Universal Serial Bus Specification”, http://www.usb.org/, May 12, 2005 Agere, Hewlett-Packard and others document. 10. ZigBee Case Study in Large Node Network SiliconLabs. Jan 21, 2013 https://www.silabs.com/support/training/Pages/zigbee-case-study-large-nodenetwork.aspx 11. Daniel Aguayo, John Bicket, Sanjit Biswas, Glenn Judd, and Robert Morris. A measurement study of a rooftop 802.11 b mesh network. In Proc. ACM SIGCOMM Conference, September 2004. 12. Sabih H. Gerez. Implementation of Digital Signal Processing: Some Background on GFSK Modulation. University of Twente, Department of Electrical Engineering.March 9, 2016 13. Godfrey Tan, Allen Miu, John Guttag and Hari Balakrishnan. Forming Scatternets from Bluetooth Personal Area Networks MIT Laboratory for Computer Science.Oct.2001 